\title{
ハンセン病療養所付設火葬場の歴史的変遷に関する研究 HISTORICAL CHANGE OF CREMATORIUMS ATTACTED TO SANATORIUMS FOR HANSEN'S DISEASE
}

\author{
浅 香勝 輔* \\ Katsusuke ASAKA
}

\begin{abstract}
In Japan is a total of sixteen sanatoriums for Hansen's disease, including national and private facilities. This paper reports a historical study of the crematoriums used at the death of patients in those sanatoriums. In former times, each of many sanatoriums had a crematorium of its own as an attached facility, and this state has been studied in detail. It is then pointed out that in these days, the use of a nearby public crematorium is increasing because of the decrease in the discriminative and prejudiced view of the general public. The special circumstances as to the four national sanatoriums still preserving attached crematoriums, have also been investigated.
\end{abstract}

Keywords : crematorium, sanatorium, district facilities 火葬場，療養所，地域施設

\section{1. 問題提起と課題}

ハンセン病はかつて「らい病」と呼ばれた。抗酸菌の 一種であるらい菌の感染によっておこる慢性伝染病で, おもに皮署と末梢神経が侵されるが，遺伝病ではない。 菌を発見したハンセン”の名をとってハンセン病とい う。

明治 33 年（1900）には，わが国に 3 万人ほどいた患 者も，昭和 18 年 (1943) に発見された優れた特効薬プ

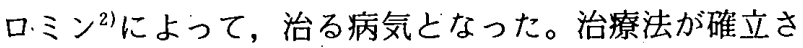
れた今日では，早期に発見し治療すれば治瘜し，社会復 帰も十分可能である。

近年わが国のハンセン病患者数は，平成 3 年 12 月 31 日現在 7130 人で，新たに発生する患者は，昭和 30 年 （1955）には 412 人だったが，平成 3 年には 17 人と激 減している。患者数 7130 人のうち, 療養所に入所患者 は 6422 人（国立 6357 人，私立 65 人），在宅患者は 708 人である。国立療養所では在園年数 30 年以上の長 期療養者が $70 \%$ を占めている3)。

過去において, 世間にはハンセン病に対し，遺伝病・ 不治の病などの偏見や差別があった。大正初期以降，わ が国で国策として強制隔離主義が採られた。その主役が 光田健輔4で，近年，光田の主導した終生隔離による八 ンセン病対策を光田イズムと呼んで, 非難する声が強い。 光田の採った方策は，確かに多くの問題があり，人権上 の疑義も少なくない占。光田が園長であった長島愛生園
の女医であった小川正子が著し，ベストセラーとなり， 映画化までされた「小島の春影も，今日では強制隔離 時代の紀行文にすぎないと断じられている7”。だが，国 家がハンセン病対策の遂行に十分な予算を与えなかった という事実との関係も，見逃してはならないであろう ${ }^{8)}$ 。

ともあれ，昭和 52 年から平成 4 年まで邑久光明園の 園長を勤めた原田禹雄氏が，「らいを病む人之精神病を 病む人を，一般的によ゙う処遇するか，ということは，そ の国の文化を測る上での指標となり得る。残念ながら， 日本は，らいを病む人々に対して苛酷であった」 べているのが至言であろう。そして今日もなお，日本の 人たちはハンセン病に対して，いわれもない偏見と差別 を捨て去っていないと思われることが多いし，治痹者の 社会復帰の道はきわめて険しい。

小稿で筆者が立てた目標は，以上のような経緯を踏ま えて，すべての国立らい療養所 ${ }^{10} \cdot$ 私立の療養所での付 設火葬場の歴史的変容亡, 現在の火葬の実態を究明し, 何らかのかたちで今後の計画への示唆を提出したいこと である。先行研究も皆無で，まだ研究者が着目しておら ず,建築学的にも境界領域として残されていて，今後開 拓されるべき課題と考えられるので，それなりの再評価 をし，次いで計画としてどう取り上げたらよいか，若干 の提言をしたい。今日，記録にとどめておかなければ， 後発研究はおろか, この主題は永遠に喪失してしまうの ではないかという責務にかられる。十分な文献・資料の

*日本大学理工学部大学院不動産科学専攻 文学修 Dept. Real Estate, Science \& Technology Nihon Univ., M. Litera., 士・博士 (工学) Dr. Eng. 
表一1 ハンセン病療養所一覧

\begin{tabular}{|c|c|c|c|c|c|}
\hline & 療 養 & 所 & 在 & 開設年月 & $\begin{array}{l}\text { 付設火葬 } \\
\text { 場の有無 }\end{array}$ \\
\hline & 国立療養所 & 松丘保盖園 & 青森県大字石江字平山 19 & 明若 42.4 & $\Delta$ \\
\hline & $"$ & 東北新生園 & 宮城県登米郡迫町新田字葉の木沢 1 & 略和 14.10 & $\Delta$ \\
\hline & $"$ & 栗生梁泉園 & 群馬県吾妻郡草津町乙 647 & 略和 7.11 & $\Delta$ \\
\hline & $"$ & 多磨全生園 & 東京都東村山市青葉町 4-1-1 & 明治 42.9 & $\Delta$ \\
\hline & 国立駿 & 河療㪇 所 & 静岡県御殿場市神山 1915 & 畎和19.12 & $x$ \\
\hline & 国立療養所 & 長島愛生園 & 岡山県芭久郡邑久町虫明 6539 & 略和 5.11 & $\Delta$ \\
\hline & $"$ & 芭久光明園 & 虫明 6253-1 & 佣 42.4 & $\mathrm{O}$ \\
\hline & $"$ & 大島青松園 & 香川県木田郡庵治町 6034 第1 & 畔台42. 4 & 0 \\
\hline & $"$ & 菊池恵楓園 & 熊本県菊池郡合志町栄 3796 & 明㘹 42.4 & $\Delta$ \\
\hline & $"$ & 星塚敬愛園 & 鹿児島県鹿屋市星塚町 4522 & 四和 10.10 & 0 \\
\hline & " & 奄美和光園 & 鹿児島県名瀬市有屋 1700 & 㖥18. 4 & $\mathrm{O}$ \\
\hline & $"$ & 沖縄愛楽園 & 沖縄県名護市字済井出 1192 & 图和13.11 & $\Delta$ \\
\hline & " & 宮古南静園 & 沖縄舆平良市字島尻 888 & 赂和 6.3 & $\Delta$ \\
\hline 私 & 財団法人 & 神山復生病院 & 静岡県御即場市神山 109 & 糋22. 5 & $x$ \\
\hline & $"$ & 身延深敬園 & 山梨県南巨摩郡身延町 3636 & 訝参39.10 & $\Delta$ \\
\hline 立 & 姏会解虫人 琵 & 琶崎待労病院 & 熊本市島崎町 6-1-27 & 朋尚 31.10 & $x$ \\
\hline
\end{tabular}

(严度4年8月31日㤢在)

きずに見落としていた付設火葬場と いう建造物を, 改めて文献・資料や 構造物から検証し, 一つの時代構成 の中に位置づけた。

また，療養所によって，文献・資 料なよ゙の記録の有無や繁簡の差もな かったわけではないが，見逃されて いた施設の画期を重点的に理解し， 叙述の適正をはかっていきたい。な お，固有・独自亡いった感性的把握 もあるであろうことを，断っておき たい。また，かつて各地に所在した 結核燎養所の付設火葬場の事情につ いては，稿を改めて論じたい。

ところで, 国立療養所の入所患者 の平均年龄は, 67.8 歳（平成 4 年 5 月 1 日現在 $\left.{ }^{121}\right)$ と高齢化し, 成人 病等の合併症による死亡者が増加し ている現在, 付設火葬場という施設 のあり方も，大きな変転期をむかえ ている。そうした情勢を踏まえて， これからの計画のあり方を, 廃絶と 存続の二つのケースに分類のうえ， 提出したい。

\section{2. 療養所付設火葬場の経年変化}

現在, わが国のハンセン病療養所 は，国立 13 か所，私立 3 か所，計 16 か所である。そのすべてを表一1

裏付けをもつとともに，踏查によって自分で確かめ,じ かに触れた観察・所見を豊富に盛り込み，一般社会から 隔絶されて，その閉塞されがちな社会のみで火葬場を保 有せねばならなかった歴史的実状を，筆者がこれまで研 究してきた常態の火葬場の研究を基盤として, 具体的に さぐるという方法をとった。そのために，できるだけ即 物的な事実の提示によって実証研究を進めたい。

さらに留意しておきたいことがある。ハンセン病は， 皮膚と末梢神経に病変を生じ, 病気が進行すると外形が 醜くなり，身体障害を残す，などの特徵があるため，有 効な治療法が無かった時代には「業病」とされていた。 一方では大正初期からの国策により, 患者は生涯を通じ て絶対に隔離すべきであるという「強烈な伝染病」説が 植え付けられた"11。こうして伝統的な「業病」観の上に, 近代的な「伝染病」観が重ね合わされたのである。

そうした社会的背景を十分念頭において，ハンセン病 がようやく終息しょうとしている今日，これまでのハン セン病療養所の生々しい歴史の中で, なかなか全体像が 分からなかった付設火葬場の実状を, 健常者が想像もで
に示し, 併せてそれぞれの開設年月, そして小稿の主題 となる付設火葬場の所在状況を表出した。国立療養所の 場合，その付設火葬場は，過去に所在したものも，現存 するものも，厚生省の所管で，すべて国有財産である。

国立療養所のうち最北端にある松丘（まつおか）保養 園には，大正 5 年 (1916) から火葬場ができ，昭和 29 年 (1954) に改築, 昭和 38 年 (1963) に廃止されている。 「昭和三十八年十二月十五日，園内の火葬廃止，青森の 火葬場で行なうことになる131 との記録がある。奉際に 建物が取り壊されたのは昭和 51 年（1976）2月10日で あったが，その直前に撮影したものが写真一1で，この 跡地には慰霊の塔が立てられている。

東北新生園では, 開設直後の昭和 15 年 (1940) 8 月 10 日に火葬場が建てられている。昭和 43 年 (1968) 11 月30日に廃止されるまで，その建物に変化はなかった が, 木造平屋建て瓦荤き, 建面積 $33 \mathrm{~m}^{2}$ であった。廃止 後は使用されないまま放置されていたが，それを撮影し たものが写真一 2 で，この建物も昭和 63 年 10 月 19 日 に取り壊されている。 


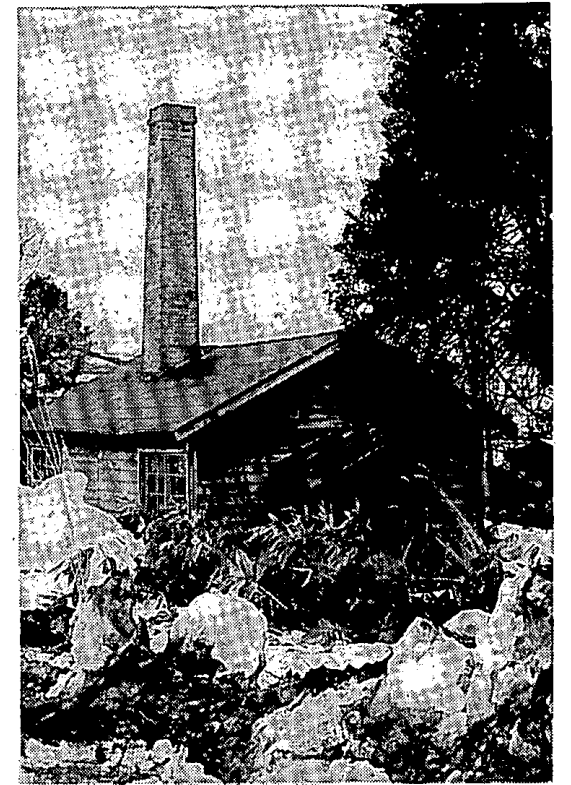

写真一1 松丘保養園付設火葬場（昭和 51 年 1 月 28 日）

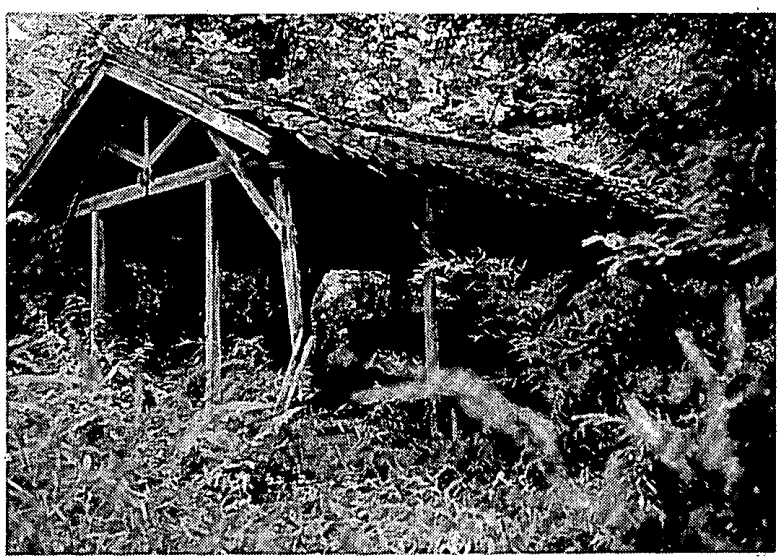

写真一2 ·東北新生園付設火葬場（昭和 63 年 8 月 24 日）

栗生（くりゅう）楽泉園には, 昭和 10 年（1935）か ら昭和 39 年 (1964) まで, 写真一3の現在では供養碑 の立っている場所に火葬場があったが，子細な記録を探 索することはできない。

多磨全生（ぜんしょう）園では，「火葬場は大正 12 年 の震災で倒壊」(4) との記録があるから, 関東大震災以前 にすでに付設火葬場が所在していたことが分かる。その 後, 再建された火葬場が所在していたことは, 古くから の入園者からのヒアリングから分かるが，いちばん新し い施設は昭和 22 年（1947）加昭和 40 年 (1965) 12 月まで, 現在の「のぞみの園」の碑がある場所に所在し ていたことが, その碑の裏面の刻銘（写真一4）によっ て判明する ${ }^{15)}$ 。しかし，建造物の記録は探索できなかっ た。

国立駿河療養所は，第二次世界大戦末期に，戦地で八 ンセン病に罹病した軍人のために開設された歴史を有す る。そのため開設当初より付設火葬場を保有しなかった

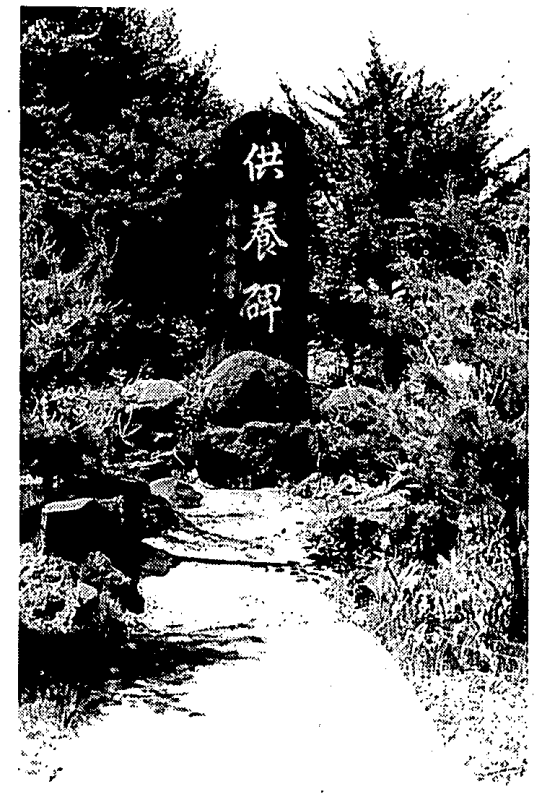

写真一3 栗生楽泉園付設火葬場跡の供養碑（昭和 63 年 6 月 5 日)

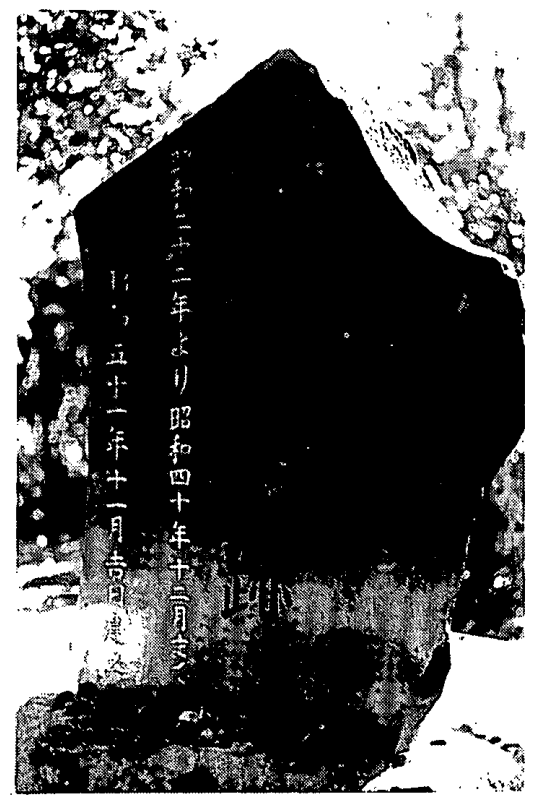

写真一4 多磿全生園付設火葬場跡の碑（昭和 60 年 11 月 4 日）

唯一の国立らい療養所である。現在では, 御殿場市の公 営火葬場を利用している。

長島愛生園が開設後, いつごろから付設火葬場を有し ていたかは，今日に至っては不詳である。ただ「昭和四 十一年九月二十八日, 万霊山の火葬場を廃止し, 光明園

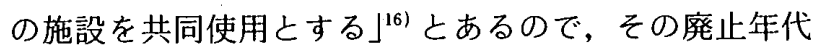
の見当はつく。

上の記録で「光明園」と記載されている邑久（おく） 光明園は，長島愛生園と同じ長島の西寄りに所在する。 岜久光明園は, 昭和 13 年 (1938) 4 月, 現在地に移転 して開設されたものである。もとは明治 42 年 (1909) 4 月に, 当時の大阪府西成郡川北村大字布屋（現在の大 阪市西淀川区中島 2 丁目，トーメン建材リースの所在す 


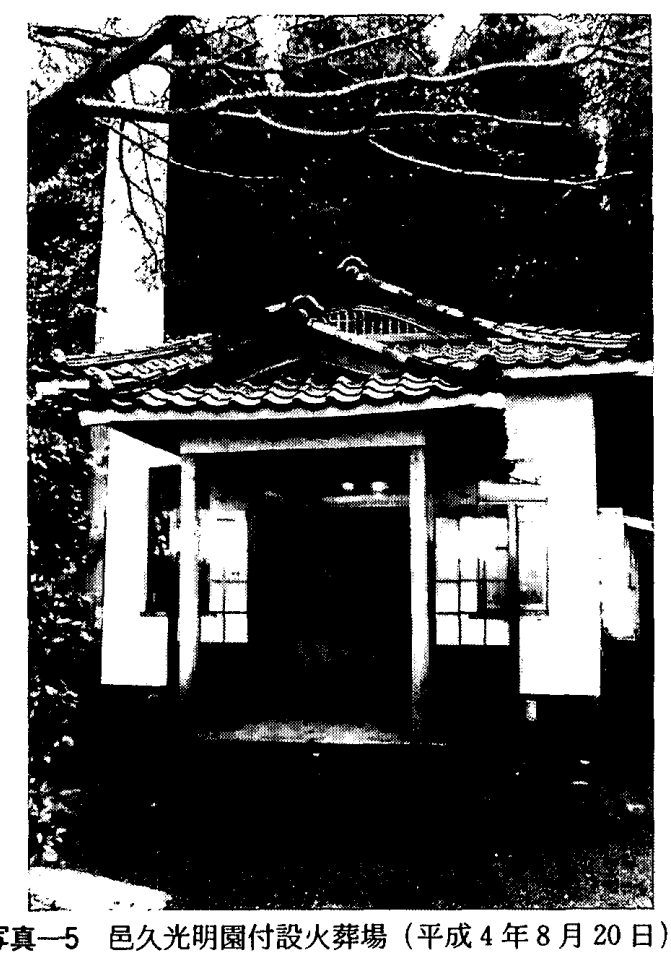

る一帯)に，外島保養院として開設されたものであった。 開設後まもなくの資料に，「患者地域の南東部約一町七 反歩は農地と火葬場, ごみ焼却場などのある地で, そこ まで出ると遠く大阪市の空が仰がれた」吾とあるから， 外島保養院の時期にも，すでに付設火葬場が存在してい たことが分かる。しかし，昭和 9 年（1934）9月 21 日

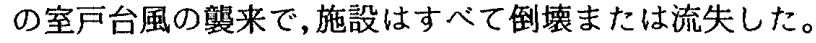
その代替施設として, 光明園と改称し, 現在地に開設し た経緯を有している。「大阪外島保養院でも光明園でも， 開園と同時に建造されていたものに, 霊安室と解剖室,

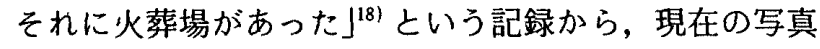
-5 の火葬場がそれであることが裏付けられるが, これ は昭和 30 年 (1955) 3 月に現存のものに建て替えられ ている。この火葬場が昭和 41 年（1966） 9 月以降, 上 述のように同じ長島に所在する長島愛生園の火葬をも引 き受けている。建物の平面図が図一1で，木造平屋建て 瓦葺き，建面積 $37 \mathrm{~m}^{2}$, 炉数 1 基である。この火葬場を 共用する㞎久光明園亡長島愛生園の, 平成に入ってから の火葬件数は表一2のとおりである。

大島青松園では，昭和 53 年（1978）12月15日に, 現在使用している鉄骨ブロック造, 壁面がモルタル刷毛 引アクリルリシン吹き付け平屋建て, 建面積が $50 \mathrm{~m}^{2}$ で 炉数 1 基の付設火葬場が，同園の所在する大島の北端に 完成している。その現況が写真一6で，平面図を図一2 に揭出しておく。それ以前の火葬場は, 現火葬場に南接 した地にあって, 現在もなお，写真一7のように，建物 と煙突を残したまま廃屋となっている。

菊地恵楓（けいふう）園には, 昭和 4 年（1929）4月 から昭和 38 年 (1963) 11 月 21 日まで付設火葬場が所

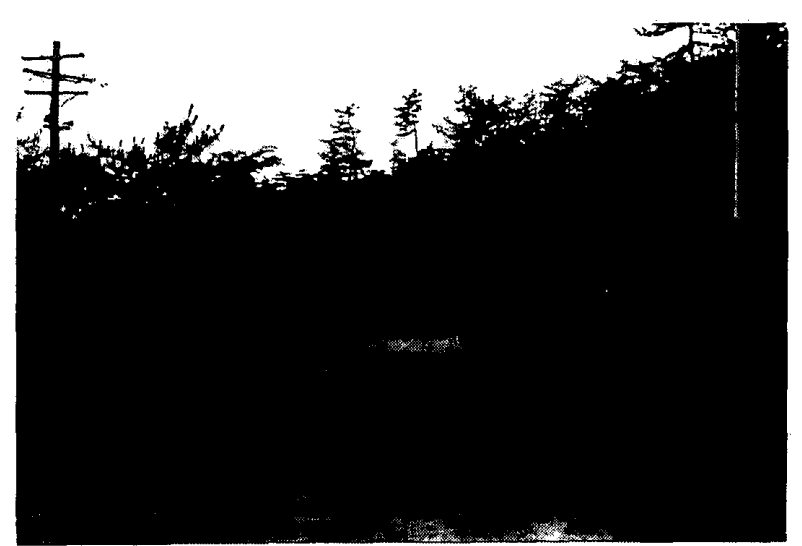

写真一6大島青松園付設火葬場（平成 3 年 6 月 18 日）

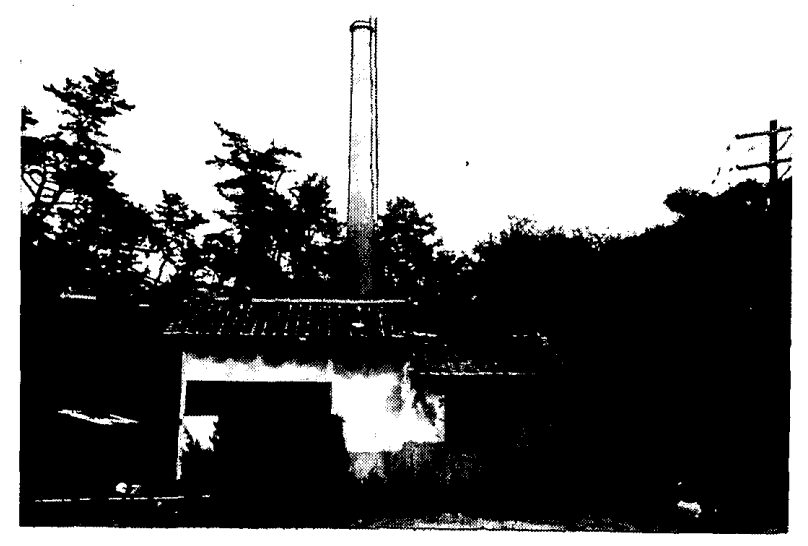

军真一7 昭和 53 年まで使用していた大島青松園付設火葬場の 廃屋（平成 4 年 8 月 9 日）

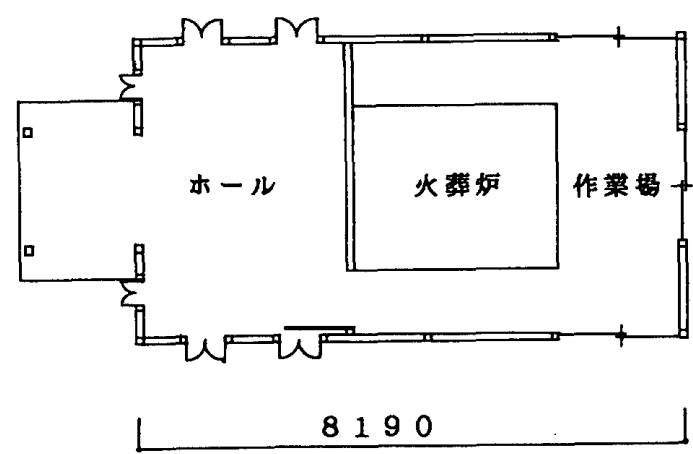

図一1 芭久光明園付設火葬場の平面図

表一2 芭久光明園と長島愛生園の火葬件数

\begin{tabular}{|c|c|c|}
\hline & 光明園 & 愛生園 \\
\hline 平成元年 & 14 件 & 23 件 \\
\hline " 2 年 & $14 \prime$ & $14 \prime \prime$ \\
\hline " 3 年 & $14 \prime \prime$ & $24 \|$ \\
\hline
\end{tabular}

（苹成4年3月31日珑在） 
在したという記録があるのみで，その詳細については， もはや探索不可能である。

星塚敬愛園の付設火葬場は, 現存する国立療養所付設 火葬場のうち，最もしょうしゃな近代的な建造物である。 鉄筋コンクリート造, 平屋建て, 建面積 $93 \mathrm{~m}^{2}$ で, 炬数 も 2 基ある。その平面図と立面図をそれぞれ図一 3 . 図一 4 に揭出しておく。昭和 58 年（1983）3 月に完工をみた

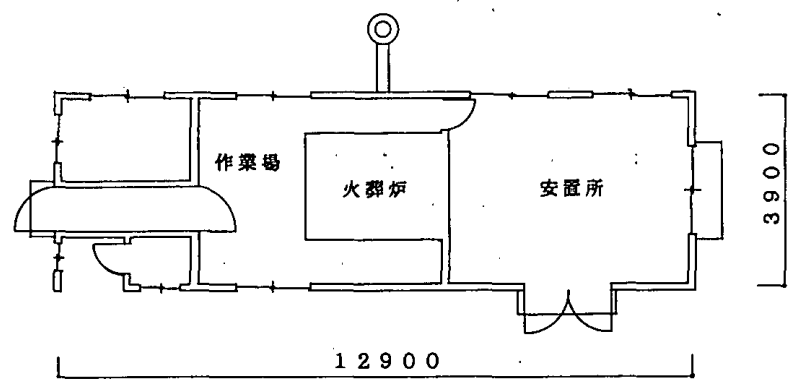

図一2 大島青松園付設火葬場の平面図

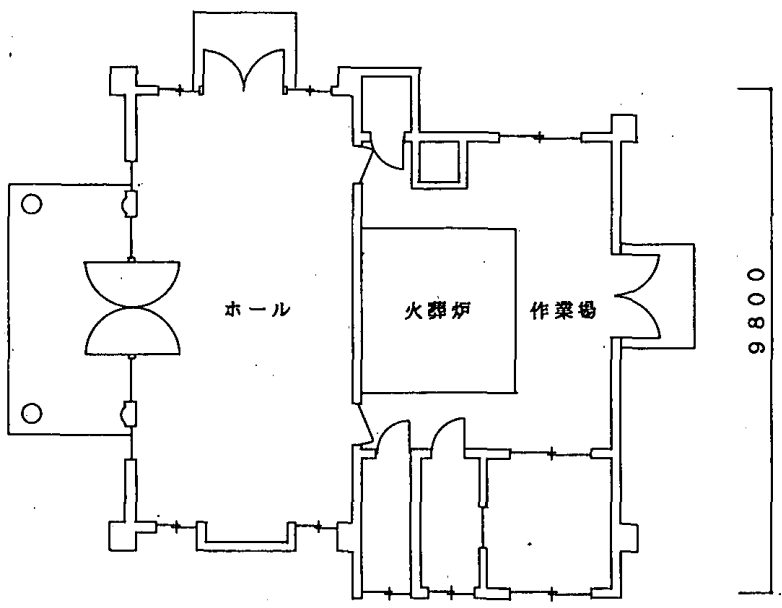

9600

図一3 星塚敬愛園付設火葬場の平面図

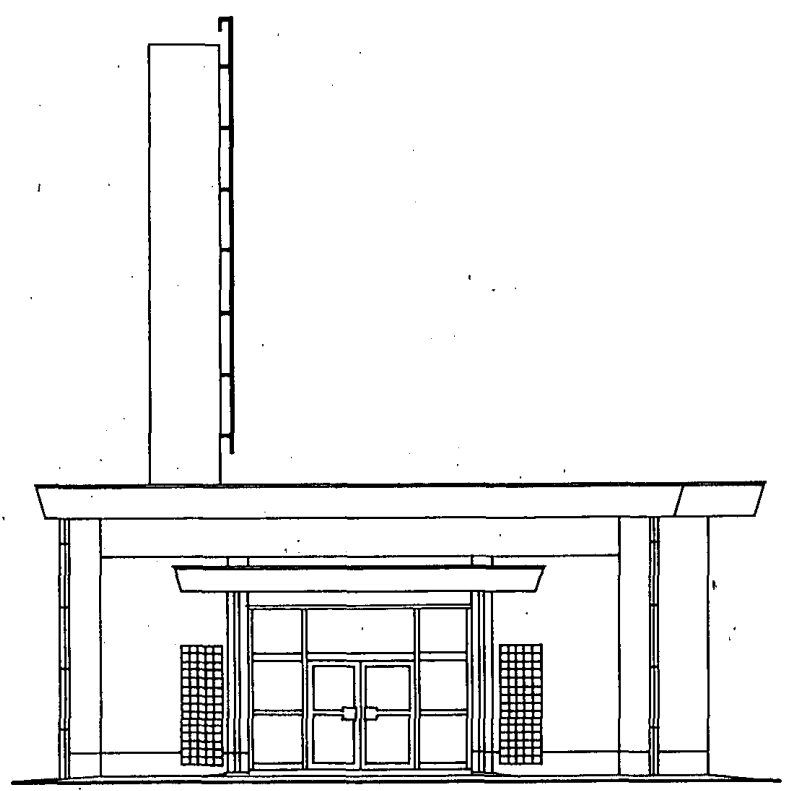

図一4 星塚敬愛園付設火葬場の西側面図
ものである。

奄美和光園には, 昭和 26 年 (1951) 3 月より付設火 葬場がある。木造平屋建てトタン直き, 建面積 $23 \mathrm{~m}^{2}$, 炬数 1 基の小規模なものである。しかし，火葬炬から炎 が噴き出して危険なため，廃止はしていないが現在は使 用していない。その平面図は図一5のとおりである。代 替施設として名瀬市の公営火葬場を利用している。

沖縄愛楽園には, 昭和 37 年（1962）8月 6 日から平 成 3 年 9 月 25 日まで付設火葬場が所在したが, 取り壊 されている。記録・資料の提示, 調査などに一切応じて もらえない。

宮古南静園には, 昭和 43 年（1968）10月に鉄筋コン クリート造, 平屋建て, 建面積 $44 \mathrm{~m}^{2}$, 炬数 1 基の付設 火葬場が建てられたが，建物の意外に早い老朽化等に よって昭和 61 年（1986）12 月で使用を中止しており, 建物はそのまま放置されているが，平成 4 年度中に取り 壊される予定である。

次いで私立の療養所の付設火葬場であるが，神山（こ うやま) 復生病院は, フランス人神父テスト＝ウィッド が設立したものである ${ }^{19)}$ 。開設以来, 付設火葬場を保有 していなかった。当初は土葬であったが, その後昭和 40 年代初期より, 国立駿河療養所之同じく御殿場市の 公営火葬場を利用して現在に至っている。

身延深敬（じんきょう）園の設立事情は，「財団法人 身延深敬園概況（平成 4 年 3 月 31 日現在)」に, 次の上 うに記されている。

明治 39 年の夏, 日蓮宗僧侶故綱脇龍妙が初めて身延山に 参詣した時，山門付近の路傍から河原にかけで幾十人のらい 患者群が悲惨なる生活をなしているのを目撃し, 殊に其の中 の一少年が聞くに耐えぬ哀れ極まる物語をして取りすがって 泣き叫び窬状を訴えたので，そのまま去る事を得ず煩悶懊悩 幾日の後, 漸く決心して救済を思ちたち, 時の身延山法主豊 永日良上人の賛助を得て, 同年 10 月 12 日仮病室を建て患者 13 名を身延河原より収容し, 事務所を清兮寺の一隅に置き, 医務を開業医遠藤源十郎に依頼, 法華経常不経菩薩品の色読 〔ママ〕を生涯の指針としていた綱脇龍妙は，この一節より， 身延深敬病院と名称を決め発足した。これが創立である。

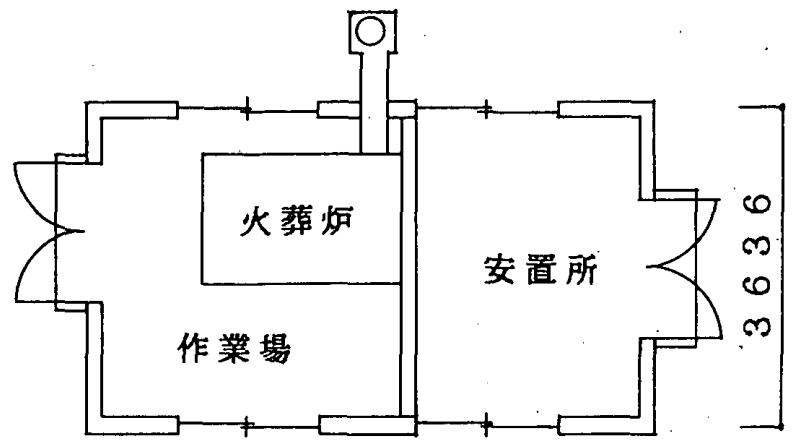

\section{3}

図一－奄美和光園付設火葬場の平面図 


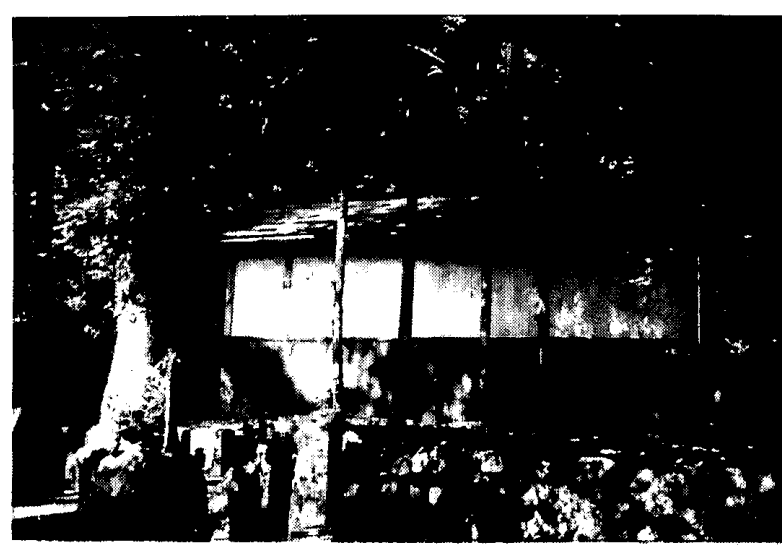

写真一8 身延深敬園付設火葬場（平成 4 年 7 月 31 日）

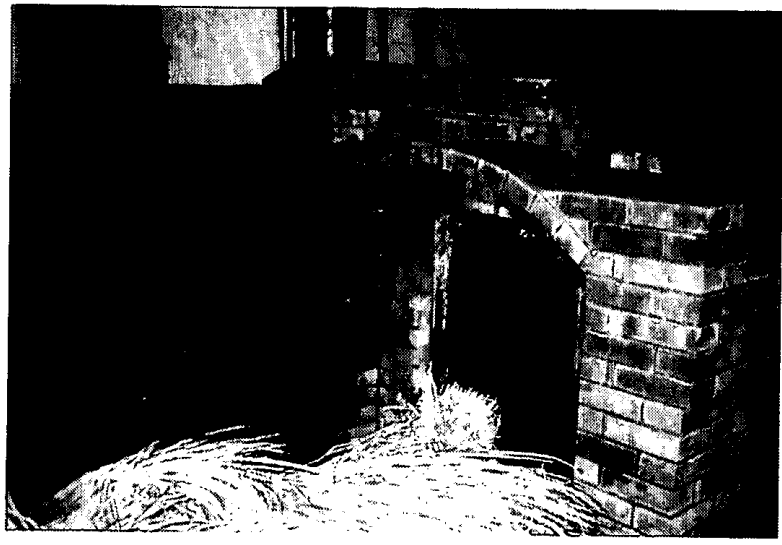

写真一9身延深敬園付設火葬場の火葬炉（平成 4 年 7 月 31 日）

ここには昭和 34 年（1959）から付設火葬場があった。 それ以前は野焼き, それより前は土葬であったという。 木造平屋建てトタン葷き, 建面積 $23 \mathrm{~m}^{2}$ の建造物は, 写 真一8のとおりである。この火葬場は入園者の手造りで 建てられ, 燃料は薪, 現在も使用可能で, その炬前状況 は写真一9のよおりであるが，昭和 61 年 (1986) より 使用しておらず，現在では身延町の公営火葬場を利用さ せてもらっている。当園の創設者である綱脇龍妙の子孫 である現園長の網脇美智女史が，筆者に，「らい療養所 の火葬場は, らいが如何に嫌われたかの一つの証言かも 知れません」と述べられた言葉の重みが忘れられない。 ちなみに，この療養所は，医学の進歩によるハンセン病 患者の减少に伴い，目的を果たしたものと考え，平成 4 年度末をもって 90 年に及ぶハンセン病療養所を閉鎖す ることになった。平成 5 年度より, 現在の社会が必要と している重度身体障害者のための身体障害者療護施設を 開園することにし，社会福祉法人の設立中である。

琵琶崎待労 (たいろう) 病院は, 私立カトリック療養 所である。カトリックは死者を葬るために土葬がならわ しであったので,昭和 31 年(1956) までは全員土葬であっ た。墓地は療養所より $2 \mathrm{~km}$ ほよ゙離れた山中にある。墓

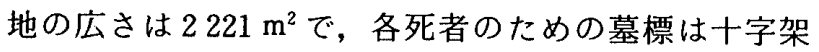
を立てた。初期は木製, 中期は腐食を防ぐためセメント
の十字架を立てたが，昭和 53 年（1978）ごろになると， 十字架も 150 余りとなり, 土地も狭あいとなったので, 十字架を取り, 同年 8 月墓碑および墓地整備工事を施行 し, 昭和 58 年（1983）1 月に納骨堂が完成したので, 䨝樹山カトリック墓地と命名し，墓地公園にしている。 その時点で，それまでの土葬による死者の骨を拾い，火 葬に付し，新しくできた納骨堂に納めている。以来，死 亡者が出たときには, 熊本市の公営火葬場で火葬し, 納 骨堂に納めている。

\section{3. ハンセン病療養所火葬問題の新しい地平}

前項のような付設火葬場の歴史的消長のなかで, 近年 に至るまで, 火葬に従事するのは，入園患者のうち軽度 の人たちが当たったという記録が多い。

青森の松丘保養園に勤務されていた厚生技官の故・牧 方勇氏が, 筆者の研究のために, 昭和 56 年 (1981) 4 月, 古くから入園していた当時 80 歳の男性患者から聞き 取ってくださった，詳細な火葬場に関するヒアリングが あるが，それを要約しておく。

大正 5 年 (1916), 患者定員 60 名になったとき，ようやく 療養所らしい建物もでき，同じくして付設火葬場もできた。 まだそのころは医療設備も完備せず，栄養状態も悪く，医療 従事者の人手不足などで，収容患者のうち毎年 $10 \%$ ほどの 人が死亡していった。特に流行性感冒などが発生すると, そ の数が $20 \%$ に及んだ年もあった。死亡患者の遺体はすべて 解剖に付されたのち，患者たちの手によって火葬された。火 葬には比較的元気な人が輪番制で当たり，1回の火葬に 3 名 が従事した。昭和初期の療養所は自給自足制を一部に採用し ており，畑作に従事する患者の 1 日当たりの作業賃は 1 銭 5 厘であったが, 火葬従事者には 1 回につき 20 銭が給付され ている。ちなみに, 刻み煙草の「なでしこ」が 1 袋 30 銭の ころのことである。

第二次世界大戦の終戦前は, 青森市の火葬場も不備で, 療 養所の職員やその家族の中でも，亡くなった場合に，この付 設火葬場で火葬してもらう人もあった。初代園長の中條資俊 氏などもこの火葬場で茶昆に付された。また療養所の近隣(当 時の新城村）の村民も，ときにはこの火葬場を利用したとい う。戦争によって食糧事情がしだいに悪化しつつあったころ でもあり，村民の火葬場利用のときには，遺族たちが労をね ぎらってくれたり，供え物がもらえるなど，いくばくかの魅 カもあったので，火葬に従事することを希望する患者も結構 多かったということである。

終戦後は, 昭和 22 年 (1947) に新楽プロミンの使用が開 始されるとともに, 死亡者の大半はハンセン病そのものが死 因でなく，老衰や一般疾病によるものがほとんどとなった。 数える程度ではあるが, 若い患者の中には将来を悲観して自 殺した者もいて，惜しまれながら療友の手によって，この火 葬場で火葬された例もあったという。火葬された患者の遺骨 はほとんど引き取る者がなく，すべて納骨堂に納められた。

昭和 24 年 (1949), 初めて入園患者たちに公職選挙法によ る選挙権が与えられたのを契機に，患者の人権の尊重が叫ば れるようになり，全国の国立療養所の患者たちが決起して全 患協を組織，らい予防法の改正を前面に，社会人なみの処遇 
改善を要求するなかで, 当時の革新系の青森市長の決断によ り，昭和 38 年（1963）12月 15 日付で, 青森市営火葬場の 使用を認められるに至った。療養所付設火葬所の老朽化之, 火葬従事者が集まらなくなったことが，反面の理由であった ともいう。

しかし，ハンセン病に対する世間の偏見はなお強く，市営 火葬場とはいえ，新しい火葬場が完成して以来使われていな かった油川の旧火葬場を，松丘保養園の死亡患者尃用とした のである。それから 10 年。青森市の人口も 26 万と増加する につれ，新しい火葬場もはや手狭となり，また，市の郊外へ 之住宅地が広がるにつれて，市の中心部に火葬場が取り残さ れるかたちとなった。昭和 47 年（1972）9月，現在の菅谷 の地に青森市斎場が完成して移転したのを機に，松丘保養園 の死亡患者も，同所で火葬されるようになった。火葬料は一 般の青森市民之同様，全額無料である。

東北新生園の記録は, ももと生々しい。同園には付設 火葬場が所在したのは昭和 15 年から 43 年までである が，同園の入園者自治会が編集・発行の『忘れられた地 の群像 東北新生園入園者自治会四十年史』(昭和 62 年, pp. 29〜31）に，次のような一節がある。

新生園の西南地で地方部落の境界ぎりぎりに火葬場があっ た。[中略〕火葬場方面は細道であり，板を四人で担くので あるが、冬季には特に難儀しながら，亡き療友を葬ったもの である。〔中略〕

火葬となると，ビういう訳か必ず夜にかかってしまう。冬 の季節の夜八時は，寒気はきびしくなり，この道路は土工係 が無報酬で造り直したものである。

この火葬のしかたについては，他の療園から転園してきた 経験者が居て適当に指導した。しかし，指導を受けて直接手 をかけるのは，地方出身の若者でこんなことは見たこともな く，脅えるのは当たりまえである。薄気味悪く，出来るなら この仕事から逃げ出したくなる。先輩から気合いをかけられ 脅えつつ仕事をする。薪で火葬をするのであるが，ある程度 の時間が経つと, 覩き穴から死人の焼け具合を見る。係員 4,5 人で状況を語り合い, ときによっては林の中から，長い 木を伐ってきて，死骸を突つき焼き易いようにする。このよ うなことになると新参者には腰が抜ける思いで，どんなに叱 られても出来ることではなかった。しかし繰り返し何回かた ずさわると慣れてくる。一昼夜に三人もしくなると火葬場も 忙しくなる。腹還いにした方が焼け易いと云えば，仏様には 遠慮なく腹這い火葬となる。時間が経って覞き穴から見ると， 真黒い顔が䮘き穴より， $\square \square^{20}$ 焼きをうらめしそうに見てい るのである。火を入れるとすぐ頭髪が燃え，髪はかたまって いる。次に目, 舅, 唇, 耳など薄肉が焼け, 真黒い顔は曾を むき出し，焼けただれた皮膚は肉裂けして白い脂部分の肉が 見える。この様は腹這いに体を入れられたために，死能はの ぞけるようになるのである。解剖された死骸を焼く時は，腹 の糸がすぐ焼け，中から腸がおどり出て，太くなり釜の中を 暴れまわり，プスッと音をたてて消えてしまうのである。

こんな゙経験をしで一人前の療養者になるわけで，こうした ことには職貣は誰れ一人顔を見せなかった。元気な者の仕事 であるが，自分の寮の人がしくなったときは、こうして行う が婦人寮の場合は男の手に委る他に術はなかった。仏に供え る物は炊事から二，三升の米之調味料が出て，お通夜は何よ りの御馳走でもあった。本職の坊さんも居らず療友でお経を 覚えている人が奉仕し, 各寮の世話役達が出席した。御馳走
のおにぎりにあずかる人はこの人々であった。この葬いも婦 人寮の場合, 男子寮を三班ぐらいに分けてその中に組入れら れ，こうした時に協力を得るようになった。

この火葬が終ると， $\square \square^{211}$ 焼き達はその寮に呼ばれ、特別 に御馳走を受ける。その翌朝遺骨拾いであるが, $\square \square^{22)}$ 焼き 達は先に出掛けてゆき, 釜の扉を開け熱気をとることにつと める。遺族によっては遗骨を持ち帰る。そのような時は夜が 明けない中に遗骨を拾うのであった。遺骨は故郷に帰る。そ んな人は生き残る療友を羡しがらせた。ライは死ねば治ると いう言葉が生まれたのはそんな事からであろう。

大部分は故啡に帰れない。死んでもその哀れさは残る。友 や寮員達が遺骨を拾って安置所に置く。阿弥陀堂と言って, 現自治会事務所裏の北東に小さな建物があった。

これは戦時中の記録である。

また，岡山の長島愛生園の記録では23)，「作業の変逗」 の項に, 昭和 11 年（1936）に日給制から月給制に切り 替えられた職種があげられているが，その中に「火葬部 等はその特殊性から[中略]これに含めた」とあるから， ここでもやはり, 軽度の患者の手による火葬が行われて いたことが分かる。

終戦直後の療養所は, 食糧を求める患者たちによって, 戦時中よりもむしろ苦痛な生活のやりくりに日を送って いた。国家の体制が新憲法の発布によって，新時代に向 かっての歩みを大きく踏み出した。それでも戦争の痛手 は大きく，容易には癒えなかった。一般の社会では敗戦 からの立ち直りは意外に早く，それを踏み台に日本経済 の全体が高度成長を遂げることになっていく。しかしそ の結果，ハンセン病療養所には，あらゆる面に大きなひ ずみがもたらされたことも覆い難い。

終戦後混乱期の栄養不足などによる死亡患者の激増 に，各燎養所の付設火葬場も新たな対応を迫られる。特 に昭和 26 年（1951）2月，全国らい患者協議会（現・ ハンセン氏病患者協議会）が発足し，大半の市民の心の 中に宿っている，ハンセン病に対する差別意識の啓蒙活 動に多大の功績を果たすことになる。やがて，ハンセン 病療養所入園患者の中の死亡者の火葬についての社会の 認識も，大きく変わってくる。昭和 30 年代後半から 40 年代にかけての時期である。

東京の多磨全生園では, 付設火葬場を昭和 40 年(1965) に廃止していると前項で記したが, 翌 41 年の 1 月に, 例外的に一人の死亡患者を火葬しているのを最後に，府 中市所在の民営火葬場を利用することとなる。これは前 述の青森の松丘保養園のケースとともに, ハンセン病療 養所で付設火葬場を保有していたものが，外部の火葬場 に火葬を依頼した初期の例である。以下，多磨全生園の 記録を点てつする ${ }^{24)}$ 。

1966 年（昭和 41 年）

1. 6 永年勤めて来た火葬係が退職, 後任が得られず, 自治会では施設に対し外部の火葬場で行うよう要 . 請したが, 話し合いがつかず紛紏する。 
22 死亡者があったが火葬の話し合いが依然としてつ いていないため，遺族らを激昂させた末，園内火 葬場で行う。火葬は雇い人夫で謝金 3000 円で行う 旨事務部長より園内に放送する。

2. 7 入園者に死亡者があり, 今回から府中の都立火葬 場を利用することになった。

1978 年（昭和 53 年）

4.20 主として火葬場行き用にとマイクロバスを購入。 近来追悼行事が派手になりつつある中で，火葬場 への送りの人数を制限し，自肃することになった。

ここに出てくる「都立」火葬場は誤りである。これは 府中市の多磨霊園の東隣に所在する民営の霊安社と称す る火葬場で, 昭和 61 年に株式会社日華と改称し, 現在 も重油炉 14 基で操業している。平成 3 年の夏,ここの 女性の専務に，多磨全生園からの遺体搬送を受け入れた 往時のことをヒアリングしたことがあるが，「葬儀屋さ んを通じて依頼された。私どもはご遺体を差別してはお りません」と，きわめて明快な答えであった。

また，前項でふれたように，その開設当初から付設火 葬場を保有しなかった国立駿河療養所と私立の神山復生 病院とは, 同じく静岡県御殿場市神山の至近地域にある が，いずれも御殿場市の公営火葬場（現在では，御殿場 市 - 小山町広域行政組合斎場の玉穂斎場公苑, 炬数 3 基) を利用している。平成 4 年 11 月 4 日に，この火葬場の 火葬技士の $\mathrm{H}$ 氏と $\mathrm{K} 氏$ から，次のようなヒアリングを得 た。上記の 2 か所のハンセン病療養所から, 年間平均 5 体ほどの火葬依頼があるという。自分たちが棺を扱うに は，職掌上差別観なよ゙まったくないが，日本自転車振興 会から寄贈された中型バスに乗って，療友だった人たち 20 名ほどが，いつもこの火葬場に同行して見えるが， 杖をついたりした身体障害を伴った人たちも多いので, 火葬場の待合室で, ほかの会葬者群が奇異の目で見てい ることが気にかかるという。火葬作業に従事する人たち の, 差別に対する視線は厳しく, 問う意味は大きい。

さらに現在では，かつて付設火葬場を保有していた八 ンセン病療養所の多くは, 近隣の地元の公営の火葬場で 火葬を行っている。ちなみに, 既述の栗生楽泉園は群馬 県吾妻郡西部火葬場で, 東北新生園は宮城県登米地方火 葬場で, 菊池恵相園は菊池葬祭場で, 沖縄愛楽園は名護 葬祭場で, 宮古南静園は平良市火葬場で, 私立では身延 深敬園が身延町火葬場を利用している。地元の火葬場側 が差別と偏見を打破した証左である。

現在も付設火葬場を保有している 4 か所の療養所で も, 往時のように軽度の患者を火葬に従事させるという ようなことはなくなっている。邑久光明園では会計課福 祉室作業係の職員 ${ }^{25}$ が, 大島青松園では同園が所在する 香川県木田郡庵治 (あじ) 町の町委嘱の人に依頼してい る。鹿児島の星塚敬愛園には専従の職員が 1 名いる。ま た, 廃止はしていないが火葬炬から炎が噴き出して危険
なため, 現在は使用していない奄美和光園では, 火葬技 士は不在となっている。

これらの現存するハンセン病療養所付設火葬場の設備 を観察すると, 近年の一般の火葬場が整備しつつある再 燃焼炉は皆無であり, 通常の火葬場の技術革新とは無縁 である。煙突から煙を出す古い設備の火葬場で, ただ焼 けばよい，という旧態依然とした設備であり, 歴史的に はさしたる進歩もないし，機能的なほかにゆとりはない。 これらのうちで若干注目すべきは, 星堟敬愛園の昭和 58 年に新しく完工した鉄筋コンクリート造の付設火葬 場は，すでに図一3で揭出したように，炉前ホールなよ゙ 告別の場が設けられていること, また, 邑久光明園・大 島青松園 - 星塚敬愛園ともに, 火葬の燃料には比較的良 質で，公害が少ないと言われているA重油が用いられて いることである。

\section{4. 検討と小括}

小稿における以上の考察の結果として，何らかのかた ちで計画への見通しないしは示唆の提出をしておく必要 がある。

小稿でまず明らかにできたことは，今日，ハンセン病 療養所付設火葬場が, 一つの画期之言うか変革期をむか えているという明確な事実である。

（1）付設火葬場を存続するケース

従来は，療養所敷地内の片隅に設けられていた例が多 い。これは山村・離村などにみられるものと軌を一にし ている立地である。それは野辺送りをするにふさわしい 距離を選んだとも考えられ，また「娧忌」の志向が療養 所側に強く働いて，隅の方に追いやったものと考察でき る。

かつては全国に散在していた結核療養所にもあった付 設の火葬場も同様であったが，このような火葬炉 1 基程 度の療養所付設の小規模火葬場の系譜は, 近世から近代 初頭にかけて，わが国の各地の集落や寺院でみられた野 焼きの習俗を考えてよい。それに加えて，ハンセン病と いう限定された人の遺体が，燎友といういわば「身内」 の人たちによって見送られるという意味が付加された。 こうした系譜を踏襲していると考えられる火葬場とし て，本来は限定された人たちが火葬される施設であって も, 今後は何よりも, 開かれた火葬場でなくてはならな W。

小稿の中でみたように，間取りは，炉前ホール（遺体 安置所・荘厳堂も含む) があって，炉の裏側に作業所が あるという, 小規模なものであり, 今後の計画上は一考 を要する。

火葬を見送る療友たちが，心をこめて遺体と最後の別 れをする炉前ホールとして, 余裕のあるスペースを持ち, 天空などから自然の明るい光を採り入れるような配慮が 
要求される。

火葬炉もまた，前室（冷却室）付きの再燃焼炉を完備 した，最新技術を駆使する清潔な火葬炉を備え，見送る 療友たちに污染された炬内を望胃させて，いたずらな不 快感や恐怖感を与えないような計画が求められる。

拾骨に際しても，身体障害を伴った療友が多いことを 考慮することが第一で，現在の存続しているすべての付 設火葬場の設備では，炬前に引き出される骨受台が非常 に高温で，身体の不自由な療友の拾骨が危険である心配 がある。拾骨台の台車も，上下の作動ができるものを使 うべきである。このためにも，炬前ホールには十分なス ペースを求めたい。それにより，炉前ホールのコーナー には祭壇設備を置き，移動式椅子を用いることにより， 簡単ながら通夜や葬儀のできる空間として計画してほし い。

建物も，小稿で言及した星塚敬愛園のように鉄筋コン クリート造りとし, 病者の会葬者を考慮した防災設備・ 避難路などを十分に考えた計画が必要である。

こうして最新の設備さえ完璧であれば，従前のように 療養所敷地内の片隅に追いやる意味も薄れてくるはずで ある。

さらに，付設火葬場には，待合室が皆無であるが，火 葬時間中に故人をしのびつつ談話できるような，ゆった りとした待合室を火葬場に併設すべきである。会葬者療 友のマイクロバスによる療棟からの往復も考えられる が, やはり落ち着いた雾囲気の, 身体障害者用のトイレ の設置などを含めて，福祉用の設備に留意した待合室の 併設計画が望ましい。

要は, 付設火葬場は, 限られた, 知り尽くした療友を 火葬する場所の典型として見直してほしい。そのうえで, 病者の心を沈思させない設備であることは言うまでもな い。

\section{（2）近隣の火葬場を利用するようになったケース}

療養所が付設火葬場を廃絶したために，ハンセン病療 養所からの遺体を受け入れるケースが増えた，近隣の地 方自治体や民営の火葬場の計画のあるべきようを示唆し ておきたい。

まず，こうした火葬場にあっても，上述の（1）の末 尾のパラグラフに記した課題の延長線上にあることを， 常に心がけるべきである。

小稿で言及した御殿場市の火葬場の火葬技士たちの証 言の例を省みるまでもなく，火葬場内で，健常者の会葬 者群と, ハンセン病療養所からの療友たちの会葬者群の 存在が，違和感のない計画をすべきである。

そのためには, 火葬炉の配置計画は, いくつもの炬を 単純に並べることをやめ，京都市中央齐場の優れた計画 のように，いくつかのブロックに火葬炬をまとめ, 別れ 亡拾骨の営為が，他の会葬集団からほぼ独立して行われ
るようにすべきである。

また，待合室は，限定された人たちが，他集団と会わ ずに休めるという計画であってほしい。それには，東京 都区部の民営火葬場にみられる特賓室のような計画が考 えられる。それは，年に何回か，八ンセン病療養所から 会葬に来る人たちのために利用されるだけでなく，一般 の会葬者用に使うべきである。当然，そこを利用する会 葬者加 ，東京都区部の民営火葬場の特賓室のように高 額の料金を徵収することはあってはならない。あくまで も個別化に重点をおくための計画である。

ともあれ, 近い将来, ハンセン病療養所は, 高㱓化現 象によって，超高齿者施設，そして障害者の療養施設に 変化していくものと考えられるが，そのときの策定の一 部に，火葬場対策をも真剣に考慮しなければならないよ きが到来している。

差別と偏見を克服しても，火葬場をめぐる計画に，け ん怠亡無関心を生みださないように求めたいというの がここの小稿のつたない真意なのである。と同時に，今 日の差別や偏見の問題に，建築学をめぐる研究も，誠実 にかかわる必要があるのではないかと省みる。

注

1） $1841 〜 1912$ 。 ルウェーの医学者。1871 年に，らい菌を 発見した。

2）アメリカのファジェーが 1943 年 9 月に創製している。わ が国で使用が開始されたのは昭和 22 年（1947）からであ る。

3）厚生省保健医療局国立療養所課の資料による。

4） 1876 1964。昭和 6 年（1931）３2 年（1957），長島愛生 園長。昭和 26 年 $(1951)$, 文化勲章を受けている。

5）原田禹雄：「この世の外机, 筑摩書房，p. 286，1992

6）初版が刊行されたのは昭和 13 年（1938），映画化は昭和 15 年 (1940) であった。

7）三宅一志：「差別者のボクに捧げる!」，晚聲社，p.10, 1978

8）注 5 前揭書, p. 286

9) 注 5 前揭書, p. 282

10）厚生省の呼称は，現在でも「らい」を使用している。

11）島比吕志：版居からの解放一ハンセン病療養所からの メッセージ ! 社会評論社, 1985 に所收の<資料 1>和 泉真蔵「日本のハンセン病はもはや“伝染病”ではない」, 同書 pp. 156 160による。

12）注 3 に同じ。

13）【秘境を開く一そこに生きて七十年一】, 松丘保養園七十 周年記念刊行委員会編，北の街社，p. $277 ， 1979$

14）【俱会一処一患者が緅る全生園の七十年一」, 多磨全生園 患者自治会編，一光社，pp. 273 274, 1979

15）注 14 前揭書にも，「昭和 51 年 12 月 10 日，火葬場跡二個 所に記念碑「のぞみの園」(中略）が建てられ，除幕式を 行う」(年表 p. 110) とある。

16）「隔絶の里程一長島愛生園入園者五十年史一」, 長島愛生 園入園者自治会編，日本文教出版，p. 309，1982

17）「風と海のなか一邑久光明園八十年のあゆみ一」，邑久光 


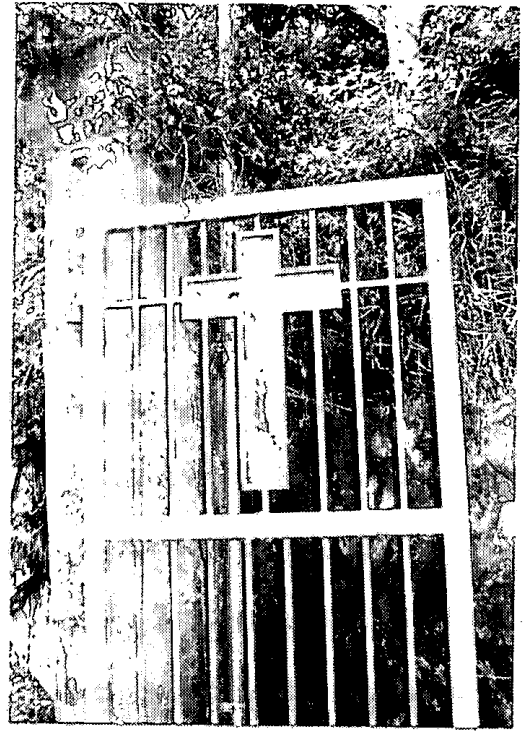

写真一10 神山復生病院の門屝に掲げられている十字架（平成 4 年11月 4 日) 明園入園者自治会編，日本文教出版，p.12，1989

18）注 17 前掲書, p. 204

19）わが国最古のハンセン病療養所であるこの病院の，十字 架が揭げられている開設当時よりの門屝が写真一10であ る。また，この療養所の初期の院長に，カトリック司祭 であり，哲学者の九鬼周造にカトリックの感化を与えた 岩下壮一がいた（田中久文：「九鬼周造」，ペリかん社， pp. 25 26, 1992)。

20）差別用語を使用しているので, 伏せ字とした。

21）注 20 に同じ。

22) 注 20 に同じ。

23）注 16 前揭書, p. 196

24）注 14 前揭書，年表 p. 92 および p. 113

25）長島愛生園と共同使用であるが，長島愛生園が火葬を行 う場合には，同園の職員が火葬に従事している。

(1992 年 12 月 28 日原稿受理, 1993 年 5 月 11 日採用决定) 